\section{Faith and loss: masterpieces from the Middlesex Hospital}

\author{
John Launer
}

Hospitals originated as religious institutions. In both the Islamic and Christian worlds, they were built alongside places of worship and made no distinction between physical and spiritual healing. Many of the world's great hospitals still bear evidence of this, and some still have beautiful ancient chapels within their precincts. Although medicine and nursing gradually became secularised in Europe from the Renaissance onwards, religious faith and regular attendance at services remained the norm, and hospitals continued to provide for these until well into the 20th century.

One of the last traditional hospital chapels to be completed in England was also one of the most spectacular. In 1891, the governors of the Middlesex Hospital, close to the centre of London, decided to erect a new chapel. It was built in memory of a former hospital chairman, Major Alexander Henry Ross. ${ }^{1} \mathrm{He}$ was a Conservative member of parliament, and an army officer who had been present at the Indian Mutiny. ${ }^{2}$ During his 21 years as a governor, he must have been highly regarded by the hospital, since it commissioned one of the most eminent architects of the time, John Loughborough Pearson, to design the chapel. Two of the hospital's leading surgeons made substantial donations towards it. Pearson had already worked on several of Britain's finest mediaeval buildings, including Bristol and Truro Cathedrals. Sadly, he died in 1897 and did not live to see the completion of the Middlesex Chapel, but the project was taken over by his son Frank, who continued to work on it for over 40 years. In the final stage, between 1929 and 1939, the original timber roof was replaced with magnificent decorated vaulting. During the same years, the original Georgian hospital was demolished and a modern one built around the chapel itself.

The chapel is built of red brick and from the outside it is unimpressive. Its glory is the interior. (See figure 1, with other images via the link in ref. 3.) Anyone who accidentally wandered in from Oxford Street-one of the busiest

Correspondence to Dr John Launer, Health Education England, Stewart House, 32 Russell Square, London WC1H 5DN, UK; johnlauner@aol.com shopping streets in London and a mere $200 \mathrm{~m}$ away-could well believe they had been transported into a heavenly dream. Pearson junior took his inspiration from Venice, Rome and Byzantium. He imported materials from around Europe, including 17 different kinds of marble and onyx. He brought craftsmen from Italy to apply these. (Shah Jahan, who built the Taj Mahal, had done the same.) Every inch of the floor, pillars and walls is covered with ornamentation. The font is carved from a solid block of green marble and is a copy of the one in the Church of Hagia Sophia in Istanbul. The lectern and basin for holy water are made of alabaster. The stained glass windows include depictions of four soldier saints including St Joan of adored by angels and the sick. The most stunning of all is the vaulted roof, built in the final years of construction-a breathtaking vision of shimmering gold, mosaics and marble.

\section{ACTS OF MERCY}

As it happens, in the years before the chapel roof was decorated, the hospital also commissioned another artistic masterpiece. It took the form of four huge paintings entitled 'Acts of Mercy.' The Arc and Saint George, as well as Christ

paintings present a complete artistic, religious and political contrast to the chapel. They were commissioned just before the First World War by a tycoon and art lover named Sir Edmund Davis, and painted by the artist Frederick Cayley Robinson. ${ }^{4}$ They depict scenes from the old Georgian hospital, which was still standing at the time, although the paintings were later installed in the entrance hall of the new hospital, just a few paces away from the chapel. Finished in 1920, they seem to allude to the horrors of war, and almost to be haunted by them. Two of the paintings show a queue of girls in the refectory of the orphanage attached to the hospital. (Ref. 5 includes a link to images of all the pictures. $)^{5}$ The orphans are dressed in identical uniforms, as they line up to receive bowls of milk. Several of the girls droop dejectedly, while one or two look directly at the viewer with expressions of deep sadness. The scene may be a reference to the similar one in 'Oliver Twist' by Charles Dickens, which was based on the workhouse in the next street. ${ }^{6}$

The other two pictures show wounded or anxious figures outside the hospital entrance. In the first of these, soldiers stand in regulation convalescent fatigues, looking listless. The final painting is perhaps the most troubling of all (see figure 2). It shows a doctor holding out his hand above a small girl and her kneeling mother. Two nurses look on, while the other onlookers include a nursing mother, an old man with a white beard and a dog with protuberant eyes. The picture seems fraught

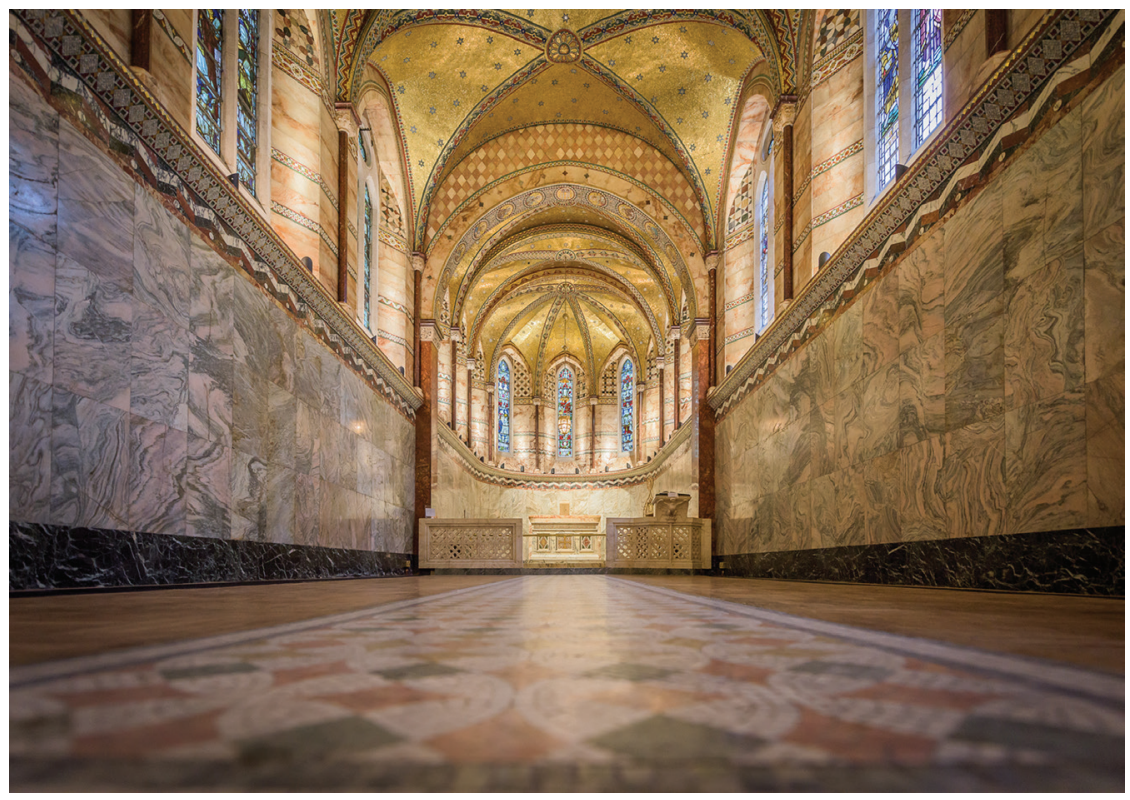

Figure 1 The Middlesex Hospital Chapel. Permission to reproduce this image was granted by The Fitzrovia Chapel Foundation (http://fitzroviachapel.org). 


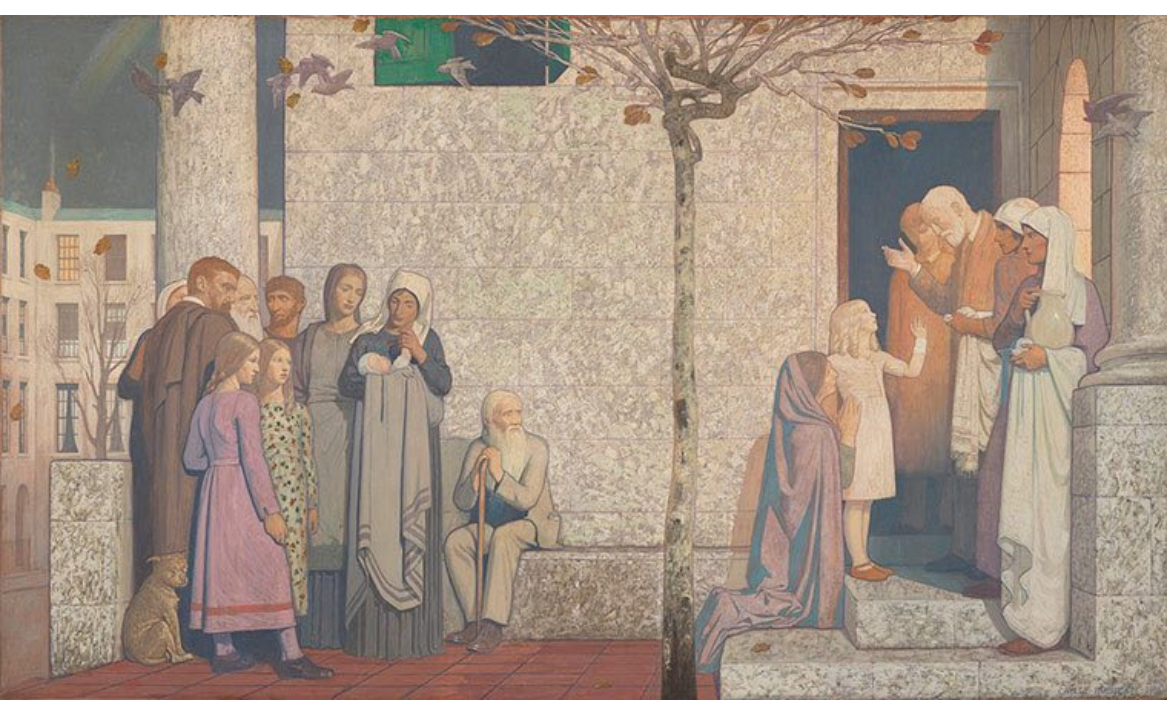

Figure 2 Acts of Mercy: The Doctor II, 1916 by Frederick Cayley. Permission to reproduce this image was granted by Wellcome Library (http://wellcomelibrary.org/).

with symbolism, but it is ambiguous. Is the doctor offering the girl a benediction, or turning her away? Is the mother kneeling in gratitude or supplication? Are the nurses concerned or angry? In the foreground, there is a birch tree with a strangely twisted and stippled branch, presumably a reference both to the serpent in the Garden of Eden, and to the hospital coat of arms, which featured three serpents. From other branches of the tree, autumn leaves fly away and seem to turn into departing swallows (a motif that was surely borrowed from the Japanese artist Hokusai). The picture is resonant with departure and loss.

When the paintings were exhibited a few years ago in the National Gallery, one art critic described their ambiguous mood as follows: 'The elements of these paintings are always pulling in different directions. You could make an atheist or pacifist out of Cayley Robinson, you could deduce a contempt for doctors who see themselves as gods, for hospitals as grand as palaces, for a system in which patients are dressed as convicts. But you could never say he was putting politics before the patients' need for visual calm and clarity.
It is precisely what allows subversion to hide in plain sight."7

\section{CONTRASTING VISIONS}

Such subversion cannot have made the governors of the Middlesex feel very comfortable. Perhaps the final, lavish reconstruction of the chapel roof during the rebuilding of the hospital was their instinctive response to this discomfort, and a way of restating their religious and military affiliations. Whether this is the case, it is extraordinary that such contrasting visions of faith and loss, of certainty and doubt, could have been commissioned by the same institution in the same era, and situated so closely to one another.

Today, the chapel remains in its place. A listed monument, it is almost the only surviving remnant of the Middlesex, which closed in 2008 and was then torn down to make way for offices, apartments and restaurants. It has been beautifully restored and is open to the public for visits and meditation on Wednesdays, as well as being available for hire under the name of 'Fitzrovia Chapel,' after the modern term for the area. ${ }^{8}$ Cayley Robinson's paintings of 'Acts of Mercy' are around half a mile away in the Wellcome Collection, London's main medical museum. ${ }^{9}$ These two artistic masterpieces from the Middlesex Hospital serve as powerful symbols of the connection between faith and medicine, and the eventual separation between them.

Twitter Follow John Launer @JohnLauner

Competing interests None declared.

Provenance and peer review Commissioned; internally peer reviewed.

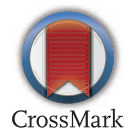

To cite Launer J. Postgrad Med J 2017;93:305-306.

Postgrad Med J 2017:93:305-306. doi:10.1136/postgradmedj-2017-134977

(c) Article author(s) (or their employer(s) unless otherwise stated in the text of the article) 2017. All rights reserved. No commercial use is permitted unless otherwise expressly granted.

\section{REFERENCES}

1 Open House London Archifacts Sheet: Fitzrovia Chapel. London: Open House London, 2015. http://www.exemplar.co.uk/site/wp-content/ uploads/2015/09/OpenHouse-London-ChapelFactsheet.pdf (accessed 24 Mar 2017).

2 Forrest GW, ed. The Indian Mutiny 1857-1858. Vol 1. New Delhi: Asian Educational Services, 2006

3 The Fitzrovia Chapel. Crimson Kettle [blog], 4 Feb 2017. http://crimsonket.blogspot.co.uk/2017/02/thefitzrovia-chapel.html (accessed 24 Mar 2017).

4 Baron JH. Frederick Cayley Robinson's Acts of Mercy murals at the Middlesex Hospital, London. BMJ 1994;309:1723-4.

5 Acts of Mercy by Frederick Cayley Robinson. The Guardian / The Observer, 25 Jul 2010. https://www.theguardian.com/artanddesign/ gallery/2010/jul/25/frederick-cayley-robinsonnational-gallery (accessed 24 Mar 2017).

6 Launer J. Memories of the workhouse. Postgrad Med 2015;91:299-300.

7 Cumming L. Frederick Cayley Robinson: Acts of Mercy. The Guardian / The Observer, 25 Jul 2010. https://www.theguardian.com/artanddesign/2010/ jul/25/cayley-robinson-national-gallery-art (accessed 24 Mar 2017)

8 The Fitzrovia Chapel. http://fitzroviachapel.org/ (accessed 24 Mar 2017).

9 Schupback W. Acts of Mercy by F. Cayley Robinson (1862-1927). Wellcome Library [blog], 29 Jan 2009. http://blog.wellcomelibrary.org/2009/01/acts-ofmercy-by-f-cayley-robinson-1862-1927/ (accessed 24 Mar 2017). 